\title{
Penerapan Metode Part-whole untuk Meningkatkan Ketrampilan Senam Ketangkasan Gerakan Round-off pada Siswa Kelas XI RPL-3 SMK Negeri 5 Malang
}

\author{
Ibnu Darmawan ${ }^{(1)}$ M.E. Winarno ${ }^{(2)}$, Agung Kurniawan \\ Universitas Negeri Malang \\ Email: ${ }^{1}$ ibnu_182@ymail.com, ${ }^{2}$ winarno_eko@yahoo.com
}

\section{Tersedia Online di}

http://www.jurnal.unublitar.ac.id/ index.php/briliant

\begin{tabular}{l}
\hline Sejarah Artikel \\
\hline Diterima pada 7 Mei 2017 \\
Disetuji pada 1 Juni 2017 \\
Dipublikasikan pada: 2 Agustus \\
2017 Hal 247-259 \\
\hline
\end{tabular}

Kata Kunci:

metode part-whole, keterampilan, senam gerakan round-off

\begin{abstract}
Abstrak: Tujuan penelitian ini adalah untuk meningkatkan keterampilan senam ketangkasan gerakan round-off siswa kelas XI RPL-3 SMK Negeri 5 Malang dengan menerapkan metode partwhole. Rancangan penelitian yang digunakan adalah Penelitian Tindakan Kelas (PTK). Subjek dalam penelitian ini adalah siswa kelas XI RPL-3 SMK Negeri 5 Malang. Kesimpulan yang didapat dari penelitian ini adalah penerapan metode partwhole dapat meningkatkan keterampilan senam ketangkasan gerakan round-off siswa Kelas XI RPL-3 SMK Negeri 5 Malang.
\end{abstract}

Sekolah sebagai lembaga pendidikan yang menyelenggarakan proses belajar mengajar, memegang peranan penting dalam rangka pembentukan sikap, pengetahuan serta budi pekerti. Pendidikan di sekolah dapat menunjang proses pertumbuhan dan pengembangan potensi yang ada pada peserta didik agar mampu menjalankan tugas-tugas kehidupan sebagai individu maupun sebagai anggota masyarakat.

Dalam kegiatan pendidikan di sekolah disajikan mata pelajaran pendidikan jasmani, olahraga dan kesehatan. Pendidikan jasmani memiliki peran penting dalam mengintensifkan penyelenggaraan pendidikan sebagai proses pembinaan manusia yang berlangsung seumur hidup. Pendidikan jasmani memberikan kesempatan kepada siswa untuk terlibat langsung dalam aneka pengalaman belajar melalui aktifitas jasmani, bermain, dan berolahraga yang dilakukan secara sistematis, terarah dan terencana. BSNP (2006: 702) menerangkan bahwa pendidikan sebagai suatu proses pembinaan manusia yang berlangsung seumur hidup. Pendidikan jasmani, olahraga, dan kesehatan yang diajarkan di sekolah memiliki peranan sangat penting, yaitu memberikan kesempatan kepada siswa untuk terlibat langsung dalam berbagai pengalaman belajar melalui aktivitas jasmani, olahraga dan kesehatan yang terpilih dilakukan secara sistematis. Pendidikan jasmani merupakan bagian integral dari pendidikan secara keseluruhan, bertujuan untuk mengembangkan aspek kebugaran jasmani, keterampilan gerak, keterampilan berpikir kritis, keterampilan sosial, penalaran, stabilitas emosional, tindakan moral, aspek pola hidup sehat dan pengenalan lingkungan bersih melalui aktivitas jasmani, olahraga dan kesehatan terpilih dan direncanakan secara sistematis dalam rangka mencapai tujuan pendidikan nasional. 
Mata pelajaran pendidikan jasmani memiliki ciri yang berbeda dari mata pelajaran lainnya. Hal ini dimungkinkan karena pendidikan jasmani sendiri menggunakan aktivitas gerak sebagai sarana untuk mencapai tujuan pembelajaran. Dalam pembelajaran pendidikan jasmani guru memberikan kesempatan siswa untuk bergerak seluas-luasnya. Penyajian materinya berupa aktivitas-aktifitas gerak yang dikemas dalam berbagai bentuk permainan dan latihan ketangkasan maupun latihan gerak dasar. Jadi dalam pembelajaran pendidikan jasmani peran guru sangat berpengaruh terhadap kesuksesan pembelajaran.

Guru pendidikan jasmani diharapkan mampu menyusun kegiatan pembelajaran yang tepat bagi siswa, sehingga membantu siswa agar dapat melakukan belajar gerak serta memotivasi siswa untuk lebih senang bergerak tanpa keraguan atau takut untuk bergerak. Maka prinsip pembelajaran yang disusun harus memperhatikan proses pembelajaran gerak dari yang paling mudah sampai tahap yang sulit, dari ringan ke berat. Seperti yang dinyatakan Syarifudin (1997:6), "Dalam proses pembelajaran, prinsip untuk dimulai dari gerak yang simpleks-kompleks-multipleks dan ringan-berat perlu dipahami oleh guru pendidikan jasmani secara lengkap". Pelaksanaan pembelajaran penjas yang baik dan tepat telak terbukti berpengaruh besar terhadap peserta didik. Keterlibatan peserta didik dalam pembelajaran penjas berkontribusi meningkatkan kemampuan fisik yang sangat bermanfaat ketika melakukan aktifitas sehari-hari (Kerr, et al, 2012:10).

Untuk mengajarkan gerak yang sulit menjadi gerakan sederhana bukanlah pekerjaan mudah, maka perlu strategi pembelajaran yang tepat sehingga dapat digunakan guru untuk membantu siswa dalam pembelajaran gerak. Terdapat beberapa macam metode yang bisa digunakan dalam proses pembelajaran. Salah satu metode yang dapat digunakan yaitu metode part-whole. Menurut Widijoto (2010:11) "Part-whole merupakan pendekatan motor learning yang mengajarkan aktivitas jasmani berdasarkan klasifikasi keterampilan dan informasi yang diterima. Part and whole (bagian-keseluruhan) akan sesuai untuk pembelajaran teknik dasar, yaitu dari bagian-bagian teknik hingga teknik secara keseluruhan."

Guru pendidikan jasmani juga harus memahami materi pembelajaran yang akan diberikan kepada siswa. Pada jenjang SMA/MA/SMK mata pelajaran pendidikan jasmani terdiri dari tujuh ruang lingkup, diantaranya yaitu: (1) permainan dan olahraga, (2) aktivitas pengembangan, (3) aktivitas senam, (4) aktivitas ritmik, (5) aktivitas air, (6) pendidikan luar kelas, dan (7) kesehatan (BSNP, 2006:703). Mencermati pada poin ke-3 yaitu aspek aktivitas senam, senam ketangkasan merupakan sub pokok materi pendidikan jasmani, olahraga dan kesehatan pada siswa kelas XI Sekolah Menengah Kejuruan (SMK). Hal ini sesuai dengan Tabel berikut:

Tabel 1 Standar Kompetensi dan Kompetensi Dasar kelas XI, Semester 2

\begin{tabular}{|c|c|}
\hline Standar Kompetensi & Kompetensi Dasar \\
\hline $\begin{array}{l}\text { 9. Mempraktikkan keterampilan } \\
\text { senam ketangkasan dengan } \\
\text { alat dan nilai-nilai yang } \\
\text { terkandung di dalamnya }\end{array}$ & $\begin{array}{l}\text { 9.2 Mempraktikkan keterampilan senam ketangkasan } \\
\text { tanpa menggunakan alat lanjutan serta nilai percaya } \\
\text { diri, kerjasama, tanggungjawab dan menghargai } \\
\text { teman }\end{array}$ \\
\hline
\end{tabular}

(Sumber: BSNP, 2006:656). 
Berdasarkan observasi awal yang dilakukan peneliti pada tanggal 24 Januari 2014, saat mata pelajaran pendidikan jasmani, olahraga dan kesehatan, dengan kompetensi senam ketangkasan gerakan round-off dari 28 siswa kelas XI RPL-3 di SMK Negeri 5 Malang diperoleh data seperti pada Tabel berikut:

Tabel 2 Data Hasil Observasi Awal Pembelajaran Senam Gerakan Round-off di Kelas XI RPL-3 SMK Negeri 5 Malang

\begin{tabular}{ccccccc}
\hline \multirow{2}{*}{ Teknik } & \multicolumn{2}{c}{ Sikap Awal } & \multicolumn{2}{c}{ Saat Melakukan } & \multicolumn{2}{c}{ Sikap akhir } \\
\cline { 2 - 7 } & Benar & Salah & Benar & Salah & Benar & Salah \\
\hline Jumlah & $\mathbf{2 3}$ & $\mathbf{5}$ & $\mathbf{4}$ & $\mathbf{2 4}$ & $\mathbf{1 3}$ & $\mathbf{1 5}$ \\
\hline Persentase & $\mathbf{8 2 , 1 4 \%}$ & $\mathbf{1 7 , 8 6 \%}$ & $\mathbf{1 4 , 2 9 \%}$ & $\mathbf{8 5 , 7 1 \%}$ & $\mathbf{4 6 , 4 2 \%}$ & $\mathbf{5 3 , 5 7 \%}$ \\
\hline
\end{tabular}

Indikator yang diamati dalam penilaian keterampilan senam round-off adalah sebagai berikut: (1) Sikap awal; (a) Berdiri dengan kaki rapat, badan tegak, (b) Pandangan mata kedepan, (c) Kedua lengan lurus ke atas. (2) Saat melakukan; (a) Melangkah satu atau dua langkah, (b) Melakukan hurdle (mengangkat salah satu kaki) kaki kiri ke depan, kemudian diletakkan di matras, (c) Telapak tangan di arahkan hingga menyentuh matras, penempatan tangan dilakukan satu persatu, (d) Kedua tungkai lurus dan rapat, posisi badan berputar $180^{\circ}$, (e) Mendaratkan kedua tungkai secara bersamaan, dengan lutut ditekuk sebentar, arah badan berlawanan dari sikap awal. (3) Sikap akhir; (a) Berdiri tegak dan kaki rapat, (b) Arah pandangan mata ke depan, (c) Kedua tangan lurus ke atas (Adisuyanto, 2009:108).

Dari pengamatan Tabel di atas muncul permasalahan di lapangan bahwa hasil keterampilan senam gerakan round-off siswa rendah. Hal tersebut terjadi karena metode mengajar guru, dalam pembelajaran round-off diketahui bahwa guru hanya menggunakan metode demonstrasi dan latihan saja. Metode tersebut guru hanya memberikan contoh gerakan secara umum dan kemudian siswa ditugaskan untuk melakukan gerakan seperti yang dicontohkan oleh guru. Guru tidak memberikan model pembelajaran secara bertahap dari tahap mudah sampai tahap yang sulit, dari tahap ringan sampai tahap yang berat untuk membantu memudahkan siswa melakukan gerakan secara keseluruhan.

Berdasarkan latar belakang masalah yang telah diuraikan di atas, maka tujuan penelitian ini adalah meningkatkan keterampilan senam gerakan round-off pada 24 siswa kelas XI RPL-3 SMK Negeri 5 Malang.

Hasil penelitian ini diharapkan dapat memberikan manfaat baik secara teoritis maupun praktis. Secara teoritis manfaat penelitian adalah meningkatkan kemampuan serta kualitas pendidik. Selain itu menambah pengetahuan, pemahaman dan wawasan baik guru ataupun siswa di dalam pembelajaran. Secara praktis penelitian ini bermanfaat bagi: (1) Bagi guru penelitian ini bermanfaat untuk memperkaya pengetahuan dan keterampilan model-model pembelajaran round-off yang sudah diperbaiki; (2) Bagi siswa penelitian ini dapat digunakan sebagai pedoman belajar bagi siswa yang akan melakukan pembelajaran senam gerakan round-off; (3) Bagi sekolah penelitian ini dapat digunakan sebagai tolok ukur untuk keberhasilan pembelajan Pendidikan Jasmani, Olahraga dan Kesehatan; (4) Bagi mahasiswa penelitian ini dapat digunakan sebagai sumber referensi bagi mahasiswa yang melakukan penelitian yang berkaitan dengan materi ini. 
Sebagai landasan dan acuan peneliti dalam melakukan penelitian, peneliti mengkaji teori-teori dan hasil-hasil penelitian yang relevan dengan masalah yang diteliti. Untuk memberikan gambaran terhadap variabel-variabel yang diteliti, maka diuraikan tentang konsep-konsep sebagai berikut:

Pengertian Senam. Istilah senam merupakan terjemahan dari bahasaInggris, yaitu: Gymnastic atau bahasa Yunaninya adalah Gymnos yang artinya telanjang yang artinya telanjang karena pada waktu itu melakukan senam dengan badan telanjang (Sudarsini, 2013:65). Senam maksudnya adalah, jika suatu kegiatan fisik yang mengandung salah satu atau gabungan dari unsur gerakan calesthenic, tumbling, acrobatic. Calesthenic berarti memperindah tubuh melalui latihan kekuatan. Tumbling adalah gerakan yang cepat dan eksplosif. Acrobatic adalah keterampilan yang menonjolkan fleksibilitas gerak dan keseimbangan (Mahendra, 1999:10). Dari pendapat di tersebut dapat disimpulkan bahwa senam merupakan aktifitas fisik dalam bentuk gerakan yang mengandung unsur calesthenic, tumbling, acrobatic.

Senam Ketangkasan Gerakan Round-off. Menurut Sudarsini (2013:75) Senam ketangkasan adalah bentuk-bentuk gerakan senam yang harus dilakukan dengan kekuatan, kecepatan, ketepatan, kelentukan, keberanian, dan kepercayaan diri dalam suatu rangkaian urutan gerak yang terpadu. Senam ketangkasan dapat dilakukan tanpa alat dan dengan alat. Salah satu bentuk gerakan dalam senam ketangkasan tanpa alat adalah gerakan round-off.

Menurut Loken dan Willoughby (1986:29) "Round-off merupakan gerak dasar berjungkir balik ke belakang". Menurut Panggabean \& Hidayat (1978:102) "Round-off adalah suatu gerakan yang terdiri dari: (1) Melakukan handstand dengan berputar pada sumbu tegak; (2) Menolak dengan kedua tangan tumpuan pada saat kedua kaki akan mendarat di lantai.

Menurut Adisuyanto (2009:108) cara melakukan teknik round-off yaitu sebagai berikut: (1) Posisi berdiri badan lurus mulai dari tangan, bahu, pinggul, sampai dengan ujung kaki dalam satu garis lurus, sikap kedua tangan di atas; (2) Langkahkan kaki kiri ke depan, bersamaan dengan ayunkan kedua tangan hingga ke belakang badan; (3) Ayun kedua tangan hingga ke atas, bersamaan dengan kaki melompat hingga badan melayangdan kedua kaki rapat ujung kaki lurus; (4) Ketika posisi kaki akan menyentuh dasar lantai, pisahkan kedua kaki dengan posisi kaki kiri ke arah depan; (5) Posisi badan dicondongkan ke depan ketika kaki kanan menyentuh dasar lantai, kaki kiri ditekuk sesuai dengan arah condong badan. Posisi kedua tangan tetap lurus ke depan dan arah pandangan mengarah ke ujung telapak tangan; (6) Arahkan kedua tangan hingga menyentuh dasar lantai, dengan terlebih dahulu meletakkan tangan kiri di dasar lantai, bersamaan dengan ayunkan kaki kanan secara kuat; (7) Letakkan tangan kanan selebar bahu dengan arah ke dalam membentuk huruf $\mathrm{T}$ bersebelahan dengan tangan kiri. Posisi badan berputar $180^{\circ}$ dan posisi kaki rapat. (8) Lecutkan kedua kaki secara kuat ke arah dasar lantai, sebelum kedua kaki menyentuh dasar lantai, tolak secara cepat kedua tangan (posisi badan melayang); (9) Ketika kedua kaki menyentuh dasar lantai, upayakan ujung kaki dan kedua lutut tetap pada posisi lurus. Begitu menyentuh dasar lantai, pantulkan kedua kaki sehingga badan turut melambung, posisi tangan lurus ke atas; (10) Lakukan pendaratan dengan menekuk kedua kaki secara lembut posisi kedua tangan tetap lurus ke depan; (11) Kembali ke sikap awal, posisi kedua tangan lurus ke atas.

250 BRILIANT: Jurnal Riset dan Konseptual Volume 2 Nomor 3, Agustus 2017 
Untuk lebih jelasnya dapat dilihat pada Gambar berikut ini:

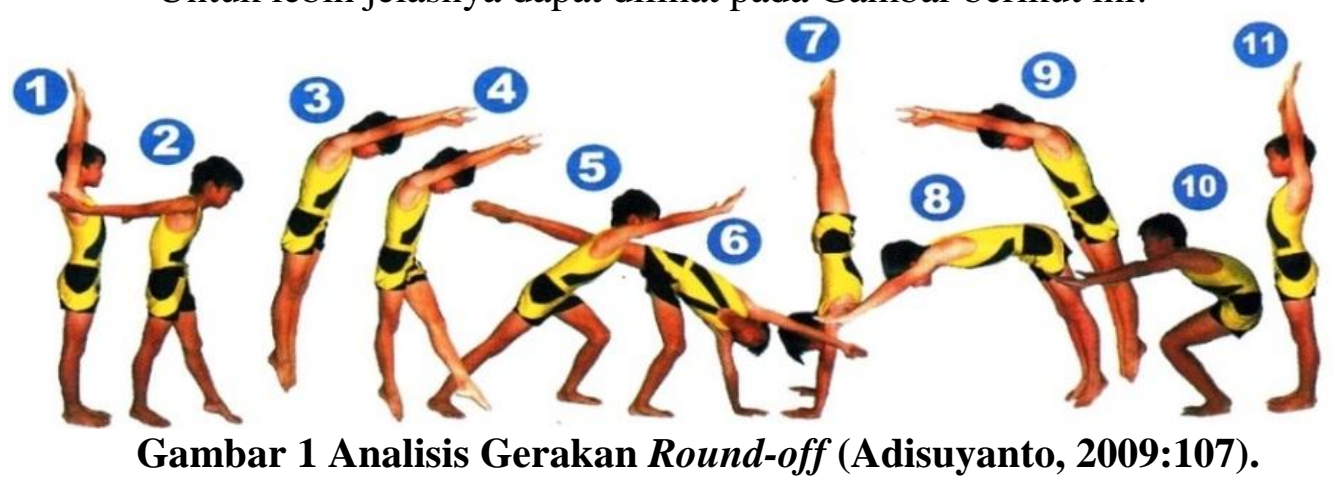

Dari penjelasan di atas dapat disimpulkan bahwa round-off adalah suatu gerakan yang terdiri dari melakukan awalan kemudian mengangkat salah satu kaki (hurdle), lalu badan diputar dengan bertumpu pada kedua tangan (handstand), kemudian mendarat dengan kedua kaki dan menghadap arah yang berlawanan.

Metode Part-Whole. Dalam strategi pembelajaran pendidikan jasmani ada beberapa macam metode yang bisa digunakan dalam proses pembelajaran. Metode yang terdapat dalam strategi pembelajaran adalah metode part (bagian) dan metode whole (menyeluruh).

Menurut Adisuyanto (2009:22), Metode bagian merupakan bentuk pembelajaran pemecahan satu bagian yang lebih kecil. Pemecahan gerak menjadi bagian terkecil, mempunyai tujuan menghilangkan atau memperkecil kemungkinan melakukan kesalahan gerak. Adisuyanto (2009:25) juga menyatakan metode menyeluruh merupakan cara mengajar gabungan pecahan bagian terkecil dari suatu gerakan menjadi gerakan yang utuh.

Menurut Widijoto (2010:11) Part-whole merupakan pendekatan motor learning yang mengajarkan aktivitas jasmani berdasarkan klasifikasi keterampilan dan teori proses informasi yang diterima, part and whole akan sesuai untuk pembelajaran teknik dasar, yaitu dari bagian-bagian dari teknik hingga teknik keseluruhan.

Di dalam motor learning/belajar gerak terdapat tahapan yang disebut tahap fiksasi, tahapan ini disebut juga tahap latihan. Pada tahap ini siswa harus mempraktekkan rangkaian gerak yang harus dikuasai. Maka dengan belajar keseluruhan dan bagian per bagian merupakan cara belajar yang cocok mengurangi kesalahan gerak yang dapat memperluas kesalahan dalam seluruh rangkaian. Menurut Rahantoknam (1988:170) Subkebiasaan-subkebiasaan yang saling tergantung sebaiknya diajarkan bagian perbagian. Hal ini cocok sekali bila kesalahan-kesalahan yang terjadi pada salah satu subkebiasaan akan menyebabkan kesalahan yang meluas dalam seluruh rangkaian. Jika siswa atau atlit tidak dapat melaksanakan satu subkebiasaan yang merupakan faktor yang sangat penting dalam menentukan keberhasilan rencana secara efektif, maka sebaiknya terlebih dahulu ia dilatih subkebiasaan tersebut secara tersendiri.

Berdasar pernyatan di atas dapat disimpulkan bahwa part-whole adalah suatu cara mengajar keterampilan gerak yang dimulai dengan cara mengajarkan bagian-bagian terkecil dari suatu keterampilan gerak, kemudian bagian-bagian tersebut digabungkan menjadi keterampilan gerak yang utuh. Sehingga metode pembelajaran dari bagian-bagian (part) hingga keseluruhan (whole) ini dapat 
membantu siswa dalam pembelajaran gerak, karena gerakan yang sulit dan kompleks dipecah perbagian menjadi bagian-bagian gerak sederhana.

\section{METODE}

Penelitian ini bertujuan untuk mengetahui bagaimana peningkatan pembelajaran round-off melalui penerapan metode part-whole pada siswa kelas XI RPL-3 SMK Negeri 5 Malang. Sesuai dengan tujuan penelitian maka pendekatan yang digunakan adalah penelitian tindakan kelas. Penelitan tindakan kelas (PTK) merupakan penelitian yang memiliki tujuan untuk meningkatkan kualitas pembelajaran. Pelaksanaan PTK dilakukan untuk menyelesaikan masalah yang dihadapi di sekolah masing-masing (Winarno, 2011:74).

Penelitian ini merupakan PTK sehingga dalam pelaksanaannya menuntut kehadiran peneliti di lapangan. Kehadiran peneliti sangat diperlukan karena peneliti juga berperan membantu guru pendidikan jasmani dalam mengamati, membuat perencanaan tindakan, pengumpulan data, penganalisa data sekaligus sebagai pelapor hasil penelitian. Dalam penelitian ini, peneliti juga dibantu oleh 2 observer yaitu Ferry Wibowo dan Fajar Inzan agar tindakan pembelajaran dapat diamati secara akurat.

PTK ini dilaksanakan di SMK Negeri 5 Jl. Ikan Piranha Atas Kota Malang. Penelitian dilaksanakan pada semester genap 2013 - 2014 pada bulan April - Mei 2014. Subjek penelitian tindakan kelas ini adalah siswa kelas XI RPL-3 SMK Negeri 5 Malang semester genap tahun ajaran 2013-2014, yang berjumlah 28 siswa.

Data yang dikumpulkan dalam penelitian ini adalah data tentang proses pembelajaran round-off. Data diperoleh dari observasi pada saat proses pembelajaran.

Sumber data penelitian ini adalah siswa kelas XI RPL-3 SMK Negeri 5 Malang. Menurut UM (2010:59) Sumber data utama biasanya adalah siswa sebagai kumpulan individu atau kelompok, karena merekalah yang secara logis dan tradisional akan menampilkan perubahan yang terjadi akibat penerapan tindakan. Pada buku tersebut juga menyebutkan bahwa Sumber data yang lain adalah guru dan dalam hal tertentu juga kepala sekolah dan staf sekolah yang lain.

Teknik pengumpulan data yang digunakan dalam penelitian ini terdiri atas: (1) Pengumpulan Data Melalui Observasi; Sugiyono (2013: 67) menjelaskan bahwa Dengan observasi di lapangan peneliti akan lebih mampu memahami konteks data dalam keseluruhan situasi sosial, jadi akan dapat diperoleh pandangan yang holistik atau menyeluruh. Observasi dilakukan oleh pengamat dengan menggunakan lembar observasi. Pengamat menggunakan lembar observasi untuk mengamati pemunculan aspek-aspek berupa perilaku guru, siswa dan berbagai hal yang terjadi selama proses pembelajaran berlangsung.

(2) Catatan lapangan; Catatan lapangan yang dibuat merupakan catatan peneliti selama pelaksanaan kegiatan mulai dari aspek suasana kelas, pengelolaan kelas, pembelajaran di kelas, hubungan interaksi antara guru dengan siswa dan siswa dengan siswa. 


\section{HASIL}

Tindakan siklus 1 dan 2 dilaksanakan pada tanggal 11 April sampai dengan 23 Mei 2014. Kesimpulan hasil dari pertemuan 1,2 dan 3 pada siklus 1 dan siklus 2 dipaparkan pada Tabel di bawah ini:

Tabel 3 Hasil Pertemuan 1, 2, 3 Pada Siklus 1 dan Siklus 2

\begin{tabular}{llll}
\hline $\begin{array}{l}\text { Persentase Tingkat } \\
\text { Keberhasilan }\end{array}$ & \multicolumn{2}{l}{ Gerakan Round-off } & \\
\cline { 2 - 4 } Sikap Awal & Saat Melakukan & Sikap Akhir \\
\hline Siklus 1 & & & \\
\hline Pertemuan 1 & $\mathbf{8 9 , 2 9 \%}$ & $\mathbf{2 1 , 4 3 \%}$ & $\mathbf{5 3 , 5 7 \%}$ \\
\hline Pertemuan 2 & $\mathbf{9 2 , 8 6 \%}$ & $\mathbf{3 5 , 7 1 \%}$ & $\mathbf{6 7 , 8 6 \%}$ \\
\hline Pertemuan 3 & $\mathbf{9 6 , 4 3 \%}$ & $\mathbf{4 6 , 4 3 \%}$ & $\mathbf{7 8 , 5 7 \%}$ \\
\hline Siklus 2 & & & $\mathbf{8 5 , 7 1 \%}$ \\
\hline Pertemuan 1 & $\mathbf{1 0 0 \%}$ & $\mathbf{6 0 , 7 1 \%}$ & $\mathbf{8 9 , 2 9 \%}$ \\
\hline Pertemuan 2 & $\mathbf{1 0 0 \%}$ & $\mathbf{7 1 , 4 3 \%}$ & $\mathbf{9 2 , 8 6 \%}$ \\
\hline Pertemuan 3 & $\mathbf{1 0 0 \%}$ & $\mathbf{8 5 , 7 1 \%}$ & \\
\hline
\end{tabular}

Mencermati Tabel di atas diketahui jumlah persentase gerakan yang benar dari siklus 1 sampai siklus 2 mengalami peningkatan, tingkat keberhasilan mulai dari aspek sikap awal dari $89,29 \%$ menjadi $100 \%$, pada aspek saat melakukan dari $21,43 \%$ menjadi $85,71 \%$, sedangkan pada aspek sikap akhir dari $53,57 \%$ menjadi $92,86 \%$.

\section{Siklus 1}

Berdasarkan data dari observasi pada pertemuan pertama diperoleh data seperti pada Tabel berikut ini:

Tabel 4 Hasil Observasi Keterampilan Senam Gerakan Round-off Pada Pertemuan 1 Siklus $1(n=28)$

\begin{tabular}{llllll}
\hline Teknik & Benar & \multicolumn{3}{c}{ Salah } & Kategori \\
\cline { 2 - 5 } & f & \% & f & $\%$ & \\
\hline Sikap Awal & $\mathbf{2 5}$ & $\mathbf{8 9 , 2 9 \%}$ & $\mathbf{3}$ & $\mathbf{1 0 , 7 1 \%}$ & Baik \\
\hline Saat Melakukan & $\mathbf{6}$ & $\mathbf{2 1 , 4 3 \%}$ & $\mathbf{2 2}$ & $\mathbf{7 8 , 5 7 \%}$ & Tidak Baik \\
\hline Sikap Akhir & $\mathbf{1 5}$ & $\mathbf{5 3 , 5 7 \%}$ & $\mathbf{1 3}$ & $\mathbf{4 6 , 4 3 \%}$ & Kurang Baik \\
\hline
\end{tabular}

Dari hasil pengamatan Tabel di atas diketahui siswa yang benar melakukan sikap awal round-off sebanyak 25 siswa atau 89,29\% dan yang salah sebanyak 3 siswa atau 10,71\% sehingga masuk dalam kategori baik. Pada teknik saat melakukan sebanyak 6 siswa atau 21,43\% yang benar dan sebanyak 22 siswa atau $78,57 \%$ yang melakukan kesalahan sehingga masuk kategori tidak baik. Sedangkan sebanyak 15 siswa atau 53,57\% yang benar dalam melakukan sikap akhir dan sebanyak 13 siswa atau 46,43\% melakukan kesalahan pada sikap akhir sehingga masuk kategori kurang baik.

Di bawah ini adalah Tabel hasil observasi pembelajaran round-off pada pertemuan kedua:

Tabel 5 Hasil Observasi Keterampilan Senam Round-off Pada Pertemuan 2 Siklus $1(n=28)$

\begin{tabular}{llllll}
\hline Teknik & Benar & \multicolumn{3}{c}{ Salah } & Kategori \\
\cline { 2 - 6 } & f & $\%$ & f & $\%$ & \\
\hline Sikap Awal & $\mathbf{2 6}$ & $\mathbf{9 2 , 8 6 \%}$ & $\mathbf{2}$ & $\mathbf{7 , 1 4 \%}$ & Baik \\
\hline Saat Melakukan & $\mathbf{1 0}$ & $\mathbf{3 5 , 7 1 \%}$ & $\mathbf{1 8}$ & $\mathbf{6 4 , 2 9 \%}$ & Tidak Baik \\
\hline
\end{tabular}

253 BRILIANT: Jurnal Riset dan Konseptual Volume 2 Nomor 3, Agustus 2017 


\begin{tabular}{llllll}
\hline Sikap Akhir & 19 & $67,86 \%$ & 9 & $32,14 \%$ & Cukup Baik \\
\hline
\end{tabular}

Dari hasil pengamatan Tabel diketahui siswa yang benar melakukan sikap awal round-off sebanyak 26 siswa atau 92,86\% dan yang salah sebanyak 2 siswa atau $7,14 \%$ sehingga masuk dalam kategori baik. Pada teknik saat melakukan sebanyak 10 siswa atau $35,71 \%$ yang benar dan sebanyak 18 siswa atau 64,29\% yang melakukan kesalahan sehingga masuk kategori tidak baik. Sedangkan sebanyak 19 siswa atau 67,86\% yang benar dalam melakukan sikap akhir dan sebanyak 9 siswa atau 32,14\% melakukan kesalahan pada sikap akhir sehingga masuk kategori cukup baik.

Di bawah ini adalah Tabel hasil observasi pembelajaran round-off pada pertemuan ketiga:

Tabel 6 Hasil Observasi Keterampilan Senam Round-off Pada Pertemuan 3 Siklus $1(n=28)$

\begin{tabular}{llllll}
\hline Teknik & Benar & \multicolumn{3}{c}{ Salah } & Kategori \\
\cline { 2 - 5 } & f & $\%$ & f & $\%$ & \\
\hline Sikap Awal & $\mathbf{2 7}$ & $\mathbf{9 6 , 4 3 \%}$ & $\mathbf{1}$ & $\mathbf{3 , 5 7 \%}$ & Baik \\
\hline Saat Melakukan & $\mathbf{1 3}$ & $\mathbf{4 6 , 4 3 \%}$ & $\mathbf{1 5}$ & $\mathbf{5 3 , 5 7 \%}$ & Kurang Baik \\
\hline Sikap Akhir & $\mathbf{2 2}$ & $\mathbf{7 8 , 5 7 \%}$ & $\mathbf{6}$ & $\mathbf{2 1 , 4 3 \%}$ & Baik \\
\hline
\end{tabular}

Dari hasil pengamatan Tabel diketahui siswa yang benar melakukan sikap awal round-off sebanyak 27 siswa atau 96,43\% dan yang salah sebanyak 1 siswa atau 3,57\% sehingga masuk dalam kategori baik. Pada teknik saat melakukan sebanyak 13 siswa atau 46,43\% yang benar dan sebanyak 15 siswa atau 53,57\% yang melakukan kesalahan sehingga masuk kategori tidak baik. Sedangkan sebanyak 22 siswa atau $78,57 \%$ yang benar dalam melakukan sikap akhir dan sebanyak 6 siswa atau 21,43\% melakukan kesalahan pada sikap akhir sehingga masuk kategori cukup baik.

\section{Siklus 2}

Berdasarkan data dari observasi pada pertemuan pertama diperoleh data seperti pada Tabel di bawah ini:

Tabel 7 Hasil Observasi Keterampilan Senam Gerakan Round-off Pada Pertemuan 1 Siklus $2(n=28)$

\begin{tabular}{llllll}
\hline Teknik & Benar & \multicolumn{3}{c}{ Salah } & Kategori \\
\cline { 2 - 5 } & f & \% & f & $\%$ & \\
\hline Sikap Awal & $\mathbf{2 8}$ & $\mathbf{1 0 0 \%}$ & $\mathbf{0}$ & $\mathbf{0 \%}$ & Baik \\
\hline Saat Melakukan & $\mathbf{1 7}$ & $\mathbf{6 0 , 7 1 \%}$ & $\mathbf{1 1}$ & $\mathbf{3 9 , 2 9 \%}$ & Cukup Baik \\
\hline Sikap Akhir & $\mathbf{2 4}$ & $\mathbf{8 5 , 7 1 \%}$ & $\mathbf{4}$ & $\mathbf{1 4 , 2 9 \%}$ & Baik \\
\hline
\end{tabular}

Dari hasil pengamatan Tabel diketahui siswa yang benar melakukan sikap awal round-off sebanyak 28 siswa atau 100\% dan tidak ada siswa yang melakukan salah sehingga masuk dalam kategori baik. Pada teknik saat melakukan sebanyak 17 siswa atau 60,71\% yang benar dan sebanyak 11 siswa atau 39,29\% yang melakukan kesalahan sehingga masuk kategori cukup baik. Sedangkan sebanyak 24 siswa atau $85,71 \%$ yang benar dalam melakukan sikap 
akhir dan sebanyak 4 siswa atau 14,29\% melakukan kesalahan pada sikap akhir sehingga masuk kategori baik.

Di bawah ini adalah Tabel hasil observasi pembelajaran round-off pada pertemuan kedua siklus kedua:

Tabel 8 Hasil Observasi Keterampilan Senam Gerakan Round-off Pada Pertemuan 2 Siklus 2 (n=28)

\begin{tabular}{|c|c|c|c|c|c|}
\hline \multirow{2}{*}{ Teknik } & \multicolumn{2}{|c|}{ Benar } & \multicolumn{2}{|c|}{ Salah } & \multirow[t]{2}{*}{ Kategori } \\
\hline & f & $\%$ & f & $\%$ & \\
\hline Sikap Awal & 28 & $100 \%$ & $\mathbf{0}$ & 0\% & Baik \\
\hline Saat Melakukan & 20 & $71,43 \%$ & 8 & $28,57 \%$ & Cukup Baik \\
\hline Sikap Akhir & 25 & $89,29 \%$ & 3 & $10,71 \%$ & Baik \\
\hline
\end{tabular}

Dari hasil pengamatan Tabel diketahui siswa yang benar melakukan sikap awal round-off sebanyak 28 siswa atau $100 \%$ dan tidak ada siswa yang melakukan salah sehingga masuk dalam kategori baik. Pada teknik saat melakukan sebanyak 20 siswa atau 71,43\% yang benar dan sebanyak 8 siswa atau $28,57 \%$ yang melakukan kesalahan sehingga masuk kategori cukup baik. Sedangkan sebanyak 25 siswa atau 89,29\% yang benar dalam melakukan sikap akhir dan sebanyak 3 siswa atau 10,71\% melakukan kesalahan pada sikap akhir sehingga masuk kategori baik.

Di bawah ini adalah Tabel hasil observasi pembelajaran round-off pada pertemuan ketiga siklus kedua:

Tabel 9 Hasil Observasi Keterampilan Senam Gerakan Round-off

Pada Pertemuan 3 Siklus $2(n=28)$

\begin{tabular}{llllll}
\hline \multirow{2}{*}{ Teknik } & Benar & \multicolumn{3}{c}{ Salah } & Kategori \\
\cline { 2 - 6 } & f & $\%$ & f & $\%$ & \\
\hline Sikap Awal & $\mathbf{2 8}$ & $\mathbf{1 0 0 \%}$ & $\mathbf{0}$ & $\mathbf{0 \%}$ & Baik \\
\hline Saat Melakukan & $\mathbf{2 4}$ & $\mathbf{8 5 , 7 1 \%}$ & $\mathbf{4}$ & $\mathbf{1 4 , 2 9 \%}$ & Baik \\
\hline Sikap Akhir & $\mathbf{2 6}$ & $\mathbf{9 2 , 8 6 \%}$ & $\mathbf{2}$ & $\mathbf{7 , 1 4 \%}$ & Baik \\
\hline
\end{tabular}

Dari hasil pengamatan Tabel di atas diketahui siswa yang benar melakukan sikap awal round-off sebanyak 28 siswa atau 100\% dan tidak ada siswa yang melakukan salah sehingga masuk dalam kategori baik. Pada teknik saat melakukan sebanyak 24 siswa atau $85,71 \%$ yang benar dan sebanyak 4 siswa atau $14,21 \%$ yang melakukan kesalahan sehingga masuk kategori baik. Sedangkan sebanyak 26 siswa atau 92,86\% yang benar dalam melakukan sikap akhir dan sebanyak 2 siswa atau 7,14\% melakukan kesalahan pada sikap akhir sehingga masuk kategori baik.

\section{PEMBAHASAN}

Berdasarkan paparan data mengenai upaya peningkatan keterampilan senam gerakan round-off, hasil kajian RPP awal peneliti memperoleh temuantemuan. Temuan-temuan peneliti tersebut yaitu; (1) materi pokok tidak disebutkan secara jelas, (2) indikator dan tujuan pembelajaran sudah dituliskan meskipun materi pokoknya belum disebutkan secara jelas, (3) pemanasan yang dibuat pada RPP tidak berupa pemanasan yang berkaitan dengan materi inti.

Selain itu hasil wawancara peneliti dengan guru diketahui bahwa guru menggunakan metode demonstrasi dan drill dalam mengajar senam gerakan 
round-off. Dari penerapan metode demonstrasi dan drill oleh guru dalam pembelajaran tersebut didapat hasil keterampilan senam gerakan round-off siswa dengan tingkat keberhasilan yang kecil. Hal tersebut terjadi karena penerapan metode yang tidak sesuai dengan materi pembelajaran.

Melihat fakta tersebut, maka peneliti mengkaji teori dan menemukan metode yang sesuai untuk diterapkan dalam pembelajaran senam gerakan roundoff. Metode yang sesuai untuk pembelajaran gerakan round-off adalah metode

part-whole. Menurut Widijoto (2010:11) "Part-whole merupakan pendekatan motor learning yang mengajarkan aktivitas jasmani berdasarkan klasifikasi keterampilan dan teori proses informasi yang diterima, part and whole akan sesuai untuk pembelajaran teknik dasar, yaitu dari bagian-bagian dari teknik hingga teknik keseluruhan".

Di dalam motor learning/belajar gerak terdapat tahapan yang disebut tahap fiksasi, tahapan ini disebut juga tahap latihan. Pada tahap ini siswa harus mempraktekkan rangkaian gerak yang harus dikuasai. Maka dengan belajar keseluruhan dan bagian per bagian merupakan cara belajar yang cocok mengurangi kesalahan gerak yang dapat memperluas kesalahan dalam seluruh rangkaian. Menurut Rahantoknam (1988:170) Subkebiasaan-subkebiasaan yang saling tergantung sebaiknya diajarkan bagian perbagian. Hal ini cocok sekali bila kesalahan-kesalahan yang terjadi pada salah satu subkebiasaan akan menyebabkan kesalahan yang meluas dalam seluruh rangkaian. Jika siswa atau atlit tidak dapat melaksanakan satu subkebiasaan yang merupakan faktor yang sangat penting dalam menentukan keberhasilan rencana secara efektif, maka sebaiknya terlebih dahulu ia dilatih subkebiasaan tersebut secara tersendiri.

Berdasar kajian teori tersebut disimpulkan bahwa metode part-whole merupakan suatu cara mengajar keterampilan gerak yang dimulai dengan cara mengajarkan bagian-bagian terkecil dari suatu keterampilan gerak, kemudian bagian-bagian tersebut digabungkan menjadi keterampilan gerak yang utuh. Sehingga metode pembelajaran dari bagian-bagian (part) hingga keseluruhan (whole) ini dapat membantu siswa dalam pembelajaran gerak, karena gerakan yang sulit dan kompleks dipecah perbagian menjadi bagian-bagian gerak sederhana.

Setelah dilakukan tindakan pada siklus 1 ada peningkatan keterampilan gerakan round-off pada siswa. Terbukti sebelum diterapkan metode part-whole tingkat kesalahan siswa paling tinggi yaitu untuk indikator saat melakukan sebanyak 24 siswa atau $85,71 \%$. Dan setelah siklus 1 persentase tingkat keberhasilan siswa meningkat, untuk indikator saat melakukan tingkat keberhasilan siswa dari 14,29\% meningkat menjadi 46,43\%.

Mencermati hal tersebut, peningkatan keterampilan pembelajaran senam gerakan round-off siswa disebabkan oleh metode yang digunakan dalam pembelajaran. Metode yang digunakan yaitu part-whole, metode ini sesuai untuk pembelajaran teknik dasar dan dapat membantu siswa dalam pembelajaran gerak karena gerakan yang sulit dan kompleks dipecah perbagian menjadi bagian-bagian gerak sederhana. Hal ini berkaitan dengan yang dikemukakan Adisuyanto (2009:22) "Metode bagian merupakan bentuk pembelajaran pemecahan satu bagian yang lebih kecil. Pemecahan gerak menjadi bagian terkecil, mempunyai tujuan menghilangkan atau memperkecil kemungkinan melakukan kesalahan gerak". Adisuyanto (2009:25) juga menyatakan "Metode menyeluruh merupakan 
cara mengajar gabungan pecahan bagian terkecil dari suatu gerakan menjadi gerakan yang utuh".

Pada pembelajaran gerakan round-off yang kompleks dipecah menjadi menjadi bagian kecil yang merupakan tahapan untuk mencapai gerakan round-off secara keseluruhan. Tahapan yang diberikan yaitu gerakan handstand, gerakan menolak dan mendaratkan kedua kaki, dan tahapan gerakan meroda.

Model-model pembelajaran round-off yang digunakan oleh peneliti dan guru pendidikan jasmani dikutip dari Panggabean \& Hidayat (1978:102-108) dan beberapa model pembelajaran peneliti kembangkan sendiri. Pembelajaranpembelajaran yang diberikan terdiri dari; (1) Pembelajaran handstand dengan bantuan, (2) Pembelajaran handstand dengan mengangkat satu tangan, (3) Pembelajaran handstand kemudian memindahkan posisi tangan, (4) Pembelajaran handstand dengan meletakkan kedua tangan menghadap ke arah datang, (5) Pembelajaran mendaratkan kedua kaki, (6) Pembelajaran menggunakan irama yang cepat, (7) Pembelajaran senam gerakan meroda, (8) Pembelajaran senam gerakan round-off.

Pada siklus 1 keterampilan siswa dalam melakukan gerakan round-off mengalami peningkatan jika dibandingkan dengan sebelum diberi tindakan. Persentase tingkat keberhasilan siswa dari aspek sikap awal 96,43\% (27 siswa), pada aspek saat melakukan 46,43\% (13 siswa), sedangkan pada aspek sikap akhir $78,57 \%$ (22 siswa).

Selain hasil mengenai hasil psikomotor, diperoleh pula hasil dari pengamatan sikap siswa pada saat proses pembelajaran, yaitu pada siklus 1 khususnya pada pertemuan 1 siswa masih melakukan pemanasan sendiri tanpa didampingi oleh guru, siswa yang terlambat tidak ditegur oleh guru, siswa yang terlambat tidak ditegur oleh guru, siswa yang menyimpang tidak segera ditegur oleh guru, siswa tidak memperhatikan penjelasan guru saat guru menjelaskan materi, dan siswa tidak serius dalam melakukan gerakan senam gerakan round-off. Pada pertemuan 2 dan pertemuan 3 mulai ada kemajuan sikap siswa seperti, siswa yang datang terlambat dan sudah ditegur oleh guru, siswa memperhatikan penjelasan guru saat guru menjelaskan materi, pengaturan waktu tiap-tiap latihan atau permainan sudah terinci dengan baik.

Peningkatan keberhasilan siswa pada siklus 1 belum sesuai target yang diharapkan oleh peneliti dan guru pendidikan jasmani, maka penelitian akan dilanjutkan pada siklus 2 untuk memperoleh peningkatan yang lebih baik bagi siswa.

Pada siklus 2 pembelajaran yang berlangsung sama seperti pada siklus 1 yaitu terdiri dari 4 tahap perencanaan, pelaksanaan, pengamatan dan refleksi. Pada tahap perencanaan peneliti berkolaborasi dengan guru pendidikan jasmani, merancang model-model pembelajaran dengan memperhatikan faktor yang dapat mempengaruhi keberhasilan siswa. Agar gerakan round-off berhasil dilakukan dengan baik menurut Panggabean \& Hidayat (1982:48) meyatakan bahwa: (1) Kesukaran pertama adalah keterampilan anak memutar badan. Hal ini akan terjadi dengan sendirinya dengan menempatkan kedua tangan penopang dengan bernalik (jari tangan menghadap arah kaki tolak); (2) Tolakan oleh satu kaki; (3) Penempatan tangan dilakukan satu persatu (walaupun terjadi dalam waktu sangat singkat/cepat); (4) Perhatiakn lemparan kaki anak tidak melalui "daerah" sisi, tidak menyamping. Lemparan kaki dilakukan seperti halnya pada handspring; (5) 
Kedua kaki harus mendarat bersama-sama dan tidak terlalu jauh dari penempatan tangan, agar mudah untuk berdiri tegak.

Kesalahan yang umum terjadi saat siswa melakukan gerakan senam gerakan round-off menurut Panggabean \& Hidayat (1978:108) meyatakan “(1) Penempatan tangan terlalu rapat, sehingga membuat badan bergoyah; (2) Badan tidak lurus, menyudut pada panggul dan paha; (3) Kedua siku-siku tangan tidak lurus; (4) Lemparan kedua kaki tidak/kurang ke atas, tetapi terlalu menyamping.

Pada tahap pelaksanaan, pembelajaran dilakukan tiga kali pertemuan. kegiatan yang dilakukan pada tahap pengamatan adalah pengambilan data berupa catatan lapangan, penilaian keterampilan senam gerakan round-off pada setiap pertemuan. Pada tahap refleksi peneliti dan guru Pendidikan jasmani mendiskusikan hasil dari pembelajaran round-off pada siklus 2 serta menentukan apakah sudah memenuhi target oleh peneliti atau perlu dilanjutkan pada siklus selanjutnya.

Pada siklus 2 keterampilan siswa juga mengalami peningkatan sehingga siswa lebih menguasai materi senam gerakan round-off yang diberikan oleh guru. Hal tersebut dapat dilihat dari persentase keberhasilan yang telah dicapai oleh siswa. Persentase keberhasilan siswa yang benar melakukan sikap awal gerakan round-off sebanyak 28 siswa atau $100 \%$ dan tidak ada siswa yang melakukan salah sehingga masuk dalam kategori baik. Pada teknik saat melakukan sebanyak 24 siswa atau 85,71\% yang benar dan sebanyak 4 siswa atau 14,21\% yang melakukan kesalahan sehingga masuk kategori baik. Sedangkan sebanyak 26 siswa atau 92,86\% yang benar dalam melakukan sikap akhir dan sebanyak 2 siswa atau 7,14\% melakukan kesalahan pada sikap akhir sehingga masuk kategori baik.

Selain hasil persentasi mengenai keterampilan senam gerakan round-off, diperoleh pula hasil dari pengamatan sikap siswa pada saat proses pembelajaran, dibandingkan dengan hasil pengamatan pada siklus 1 maka pada siklus 2 ini sudah terlihat peningkatan yang baik, sudah tidak ada siswa yang terlambat, siswa yang menyimpang menjadi lebih disiplin, siswa melakukan proses belajar dengan baik, dan siswa sudah menguasai keterampilan senam gerakan round-off dengan baik dan benar.

\section{KESIMPULAN}

Penerapan metode part- whole dapat meningkatkan keterampilan senam ketangkasan gerakan round-off pada siswa kelas XI RPL-3SMK Negeri 5 Malang. Peningkatan keterampilan siswa dengan metode part-whole dapat dilihat dari tingkat keberhasilan siswa melakukan keterampilan senam ketangkasan gerakan round-off dari setiap pertemuan.

Selain peningkatan keterampilan, terjadi pula peningkatan dalam hal aktivitas siswa dalam pembelajaran, sudah tidak ada siswa yang terlambat, siswa yang menyimpang menjadi lebih disiplin, siswa melakukan proses belajar dengan baik, dan siswa sudah menguasai keterampilan senam ketangkasan gerakan round-off dengan baik dan benar.

\section{SARAN}

Berdasarkan hasil penelitian, saran yang dapat diberikan adalah: bagi guru pendidikan jasmani, olahraga dan kesehatan terkait hasil penelitian dari peningkatan keterampilan senam ketangkasan gerakan round-off siswa mencapai 
$85,71 \%$ dapat ditingkatkan lagi hingga mencapai hasil maksimal. Guru pendidikan jasmani, olahraga dan kesehatan dapat menjadikan hasil penelitian ini sebagai sumber referensi untuk memperkaya pengetahuan guru dalam mengajar. Bagi siswa harus lebih belajar keras dan bersungguh-sungguh dalam pembelajaran pendidikan jasmani khususnya materi senam ketangkasan gerakan round-off karena butuh latihan berkala agar siswa lebih terampil. Saran yang terakhir yaitu penerapan metode part-whole sebaiknya juga diterapkan pada kelas yang mengalami permasalahan sama agar keterampilan gerak siswa dapat meningkat.

\section{DAFTAR RUJUKAN}

Adisuyanto. 2009. Cerdas dan Bugar Dengan Senam Lantai. Jakarta: Grasindo. BSNP. 2006. Standar Isi Sekolah Menegah Atas/Madrasah Aliyah/Sekolah

Menengah Kejuruan/MadrasahAliyah. Jakarta: Badan Standar Nasional Pendidikan.

Kerr, et all. 2012. Physical Education Contributes to Total Physical Activity

Levels and Predominantly in Higher Intensity Physical Activity Categories: European Physical Education Review, 1-13.

Loken, Newton. C dan Willoughby, R. J. 1986. Petunjuk Lengkap Gimnastik: Membahas Program Latihan dan Teknik. Semarang: Dahara Prize.

Panggabean \& Hidayat. 1978. Senam dan Metodik 1b. Jakarta: PT. Sinar Hudaya. Panggabean \& Hidayat. 1982. Senam Lantai 1b. Jakarta: PT.Sinar Hudaya.

Rahantoknam. 1988. Belajar Motorik: Teori dan Aplikasinya dalam Pendidikan Jasmani dan Olahraga. Jakarta: Departemen Pendidikan dan Kebudayaan.

Sudarsini. 2013. Pendidikan Jasmani dan Olahraga. Malang: Kementerian Pendidikan dan Kebudayaan

Sugiyono. 2013. Metode Penelitian Pendidikan Pendekatan Kuantitatif, Kualitatif dan R\& D. Bandung: Alfabeta.

Syarifudin. 1997. Pokok-Pokok Pengembangan Program Pembelajaran Pendidikan Jasmani. Jakarta: Departemen Pendidikan dan Kebudayaan.

UM. 2010. Pedoman Penulisan Karya Ilmiah: Skripsi, Tesis, Disertasi, Artikel, Makalah, Tugas Akhir dan Laporan Penelitian. Malang: Universitas Negeri Malang.

Widijoto, H. 2010. Strategi Pembelajaran Pendidikan Jasmani Olahraga dan Kesehatan. Malang: Universitas Negeri Malang.

Winarno. 2011. Metode Penelitian dalam Pendidikan Jasmani. Malang: Media Cakrawala Utama Press. 